\title{
Effects of Heat Shock and 2,4-D Treatment on Morphological and Physiological Characteristics of Microspores and Microspore-Derived Doubled Haploid Plants in Brassica napus L.
}

\author{
Fatemeh Pourabdollah Najafabadi 1,2, Mehran Enayati Shariatpanahi 1,*, Behzad Ahmadi ${ }^{1}$, Nayerazam \\ Khosh-Kholgh Sima ${ }^{3}$, Bahram Alizadeh ${ }^{4}$, Mahnaz Oroojloo ${ }^{1}$ \\ ${ }^{1}$ Department of Tissue Culture and Gene Transformation, Agricultural Biotechnology Research Institute of Iran (ABRII), \\ Karaj, Iran \\ ${ }^{2}$ Department of Biology, Faculty of Science, Shahid Chamran University, Ahwaz, Iran \\ ${ }^{3}$ Department of Molecular Physiology, Agricultural Biotechnology Research Institute of Iran (ABRII), Karaj, Iran \\ ${ }^{4}$ Department of Oilseeds Research, Seed and Plant Improvement Institute (SPII), Karaj, Iran
}

${ }^{*}$ Corresponding author: Mehran E. Shariatpanahi, Department of Tissue Culture and Gene Transformation Agricultural Biotechnology Research Institute
of Iran (ABRII), Karaj, Iran. Tel: +98-2612703536, Fax: +98-2612704539, E-mail: mehran.shariatpanahi@abrii.ac.ir; m_shariatpanahi2002@yahoo.com

Received: February 02, 2015; Revised: May 11, 2015; Accepted: May 27, 2015

Background: Stresses such as heat shock, starvation, or osmotic is essential to lead isolated microspores towards embryogenesis. Despite the effectiveness of stresses in embryogenesis, they exert adverse effects on metabolism and growth of the regenerated plants.

Objectives: The effects of heat shock and 2,4-D treatment on total protein content of treated microspores, morphological and physiological characteristics of the doubled haploid (DH) plants were assessed.

Materials and Methods: Buds containing mid- to late- uninucleate microspores were used for microspore culture. Microspores were isolated and cultured in NLN-13 medium and incubated at $30^{\circ} \mathrm{C}$ for 14 days or treated with 2,4-D (35 mg. $\mathrm{L}^{-1}$ ) for $30 \mathrm{~min}$ to induce embryogenesis. Microspore-derived embryos were transferred onto B5 medium for plantlet regeneration. Ploidy level of the regenerated plantlets was determined using Partec flow cytometry. Spectrophotometric readings were carried out at 490, 663 and $645 \mathrm{~nm}$ to determine $\mathrm{Chl} \mathrm{a}-\mathrm{b}$ and carotenoids contents. TRIzol and cetyl-threeethyl-ammonium bromide (CTAB) were used for protein extraction from microspores and leaves. Length and width of stomata and pollen grains were also photographed using light microscope (Olympus).

Results: Applied stressors significantly reduced total protein content of treated microspores however, protein content and concentration of chlorophyll a and b of the DH plants were only increased by heat shock treatment when compared with the donor plant 'Hyola 420'. In contrast, carotenoids were not affected by applied stressors. Longer and wider stomata were observed by 2,4-D treatment but, the length of pollen grains was significantly decreased following heat shock and 2,4-D treatment.

Conclusions: Total protein content of cultured microspores, concentration of chlorophyll a and $b$, length and width of stomata of microspore-derived doubled haploid plants were significantly affected by the type of inductive stresses. However, carotenoids were more stable and not affected by applied stressors.

Keywords: Doubled haploid (DH); Microspore embryogenesis; Photosynthetic pigment; Protein content

\section{Background}

Isolated microspore culture is likely to remain a prominent method in plant breeding programs as it allows for the rapid production of DH plants while, in the context of developmental biology, it allows for in vitro embryogenesis to be explored in a greater detail (1). Comprehensive utilization of $\mathrm{DH}$ production via isolated microspore culture system has been incorpo- rated into Brassica breeding programs as well as gene transformation, biochemical and physiological studies (2). However, all these applications depend heavily on the efficiency of microspore embryogenesis and subsequent plant regeneration.

Isolated microspores, when given the optimal combination of culture conditions and stresses, can be diverted from the normal gametophytic developmental 
pathway towards sporophytic pathway, and subsequently produce embryos and haploid or DH plants (3, $4,5)$. In Brassica, microspores are usually induced by heat shock pretreatment $(6,7)$ and its duration $(8)$, osmotic stress $(6,9)$, chemical inducers such as 2,4-D (10), mutagenic agents (11) or stress hormones (5). Exposure of isolated microspores to high temperature is considered to be a key factor for embryogenesis induction. Working on B. napus microspore culture, Ahmadi et al. (8) noted that elevated temperature $\left(30^{\circ} \mathrm{C}\right)$ not only efficiently induced microspore embryogenesis but also accelerated the process of embryogenesis. Heat shock influences microtubule distribution, blocks further gametophytic development, during which, acentric nucleus migrates to more central position and mitosis ultimately results in a symmetrical division with two daughter cells, similar in size and organelle distribution $(3,12,13)$.

$2,4-\mathrm{D}$, a synthetic auxinic herbicide, is an appreciated chemical inducer of microspore embryogenesis (10). According to Ardebili et al. (10), 2,4-D at 15-45 mg.L.-1 for 15-45 min, induces microspore embryogenesis in B. napus. However, the frequency of embryo production and normal plantlet regeneration were lower in comparison to the heat shock $\left(30\right.$ or $32.5^{\circ} \mathrm{C}$ ) treatment (10). In addition, 2,4-D has been widely used for embryogenesis induction in somatic cells of Hylomeconvernalis (14) and zygotic cells of Arabidopsis thaliana (15). 2,4-D acts not only as an exogenous auxin analogue, but also as an abiotic stressor (16). Although such stresses efficiently induce microspore embryogenesis, they exert adverse effects on metabolism and growth of the regenerated plants and adaptation to such stresses depends heavily on the series of morphological, physiological and biochemical adjustments (17).

\section{Objectives}

In this study, the effects of two inductive stresses i.e. heat shock and 2,4-D treatment on total protein content of treated microspores, morphological (length and width of guard cells, length of pollen grains) and physiological characteristics (protein content and concentration of pigments of photosynthesis) of the derived DH plants were assessed.

\section{Materials and Methods}

\subsection{Donor Plants and Growth Conditions}

Rapeseed (B.napus L.)cv. 'Hyola 420' was the test plant. Donor plants were grown in a growth chamber at a day/night temperature of $25 / 20^{\circ} \mathrm{C}$ with $16 \mathrm{~h}$ photoperiod and light intensity (PFD) of $400 \mu \mathrm{Em}^{-2} \mathrm{~s}^{-1}$. Plants were irrigated with $0.5 \mathrm{mg} . \mathrm{L}^{-1}$ N.P.K. and 0.3 mg.L.-1 micronutrients (Green More) two times a week.

\subsection{Microspore Culture and Microspore-derived Embryo (MDE) Regeneration}

Flower buds (2.5-3.5 mm in length) containing a mixed population of mid- to late- uninucleate microspores were harvested from the main and lateral branches of the donor plants that had reached anthesis after about 80-100 days of culture. Harvested buds were immersed in $3.5 \%$ sodium hypochlorite (Golrang ${ }^{\circledR}$, Tehran, Iran) with gentle shaking for 15 min followed by three 5 -min washes with cold $\left(4^{\circ} \mathrm{C}\right)$ sterile distilled water. Approximately 90-100 sterilized buds were placed in a glass tube and gently macerated into $15 \mathrm{~mL}$ of liquid NLN-13 (18)medium supplemented with 13\% (w/v) sucrose (DuchefaBiochemie, Haarlem, The Netherlands) using a sterile glass rod. The crude suspension was filtered through a $50 \mu \mathrm{m}$ nylon mesh, collected into two $50 \mathrm{~mL}$ centrifuge tubes and the volume was adjusted with fresh NLN-13 medium to $25 \mathrm{~mL}$. The filtrate was centrifuged at $100 \times \mathrm{g}$ for $5 \mathrm{~min}$ at $4^{\circ} \mathrm{C}$. The supernatant was decanted and the pellet was rinsed in fresh NLN-13 medium. This procedure was repeated twice. Finally the plating density was adjusted to $2 \times 10^{4}$ microspores $/ \mathrm{mL}$ using a hemocytometer (Precicolor, Germany). Microspore suspension $(5 \mathrm{~mL})$ was dispensed into $6 \mathrm{~cm}$ sterile plastic Petri dishes (Farazbin ${ }^{\circledR}$, Tehran, Iran). Cultures were incubated either at $30 \pm 0.5^{\circ} \mathrm{C}$ in dark for 14 days or treated with 2,4-D (35 mg. $\left.\mathrm{L}^{-1}\right)$ for $30 \mathrm{~min}$, and transferred to $25 \pm 1^{\circ} \mathrm{C}$. Once embryos were visible to the naked eye,the Petri dishes were transferred onto a rotary shaker in dark at $55 \mathrm{rpm}$.

MDEs measuring 4-6 $\mathrm{mm}$ in lengthwere transferred onto B5 medium (19) containing $0.1 \mathrm{mg} . \mathrm{L}^{-1}$ gibberellic acid $\left(\mathrm{GA}_{3}\right.$, Fluka, Buchs, Switzerland), 2\% $(\mathrm{w} / \mathrm{v})$ sucrose, $\mathrm{pH} 5.7$ and $0.7 \% \quad(\mathrm{w} / \mathrm{v})$ agar (DuchefaBiochemie). Following incubation at $4 \pm$ $0.5^{\circ} \mathrm{C}$ in dark for 10 days, the Petri dishes were maintained at $25 \pm 1^{\circ} \mathrm{C}$ under a $16 \mathrm{~h}$ photoperiod with light intensity of $40 \mu \mathrm{E} / \mathrm{m}^{2} / \mathrm{s}^{1}$ for 1 week. The MDEs were placed onto B5 medium containing $1 \%(\mathrm{w} / \mathrm{v})$ sucrose, $\mathrm{pH} 5.7,0.9 \%(\mathrm{w} / \mathrm{v})$ agar with no $\mathrm{GA}_{3}$ for plantlet regeneration (11). Regenerated plantlets were transferred to pots containing sterile peat and perlite $(1: 1$ $\mathrm{v} / \mathrm{v}$ ) and maintained in a growth chamber at $24 \pm 1^{\circ} \mathrm{C}$ 
under a $16 \mathrm{~h}$ photoperiod with light intensity of 150 $\mu \mathrm{Em}^{-2} \mathrm{~s}^{-1}$ for 2 weeks. Gradual adaptation to greenhouse conditions was then followed.

\subsection{Determination of Ploidy Level and Chromosome Doubling}

Ploidy statues/DNA content of regenerated plants was determined using flow cytometry (PA, Partec, $\mathrm{GmbH}$, Münster, Germany). Segments measuring 7-10 $\mathrm{mm}$ in diameter from young leaves were finely chopped using a sterile surgical blade in $400 \mu \mathrm{L}$ OTTO extraction buffer (20) for the isolation of nuclei. Extraction solution $(1600 \mu \mathrm{L})$ containing DNAspecific fluorochrome 4,6-diamino-2-phenylindole (DAPI) (21) was added and the solution was filtered through $50 \mu \mathrm{m}$ nylon filter mesh. After 2-3 min incubation in the extraction solution, the filtrate was immediately analyzed with flow cytometer. Measuring about 12000 nuclei, the relative content of DNA was determined.

Haploid plants without any obvious phenotypic abnormalities were treated with colchicine to induce chromosome doubling. Once the plants were removed from the pots, the roots were washed with tap water. The roots of these plants were submerged in a $0.34 \%$ colchicine (Sigma-Aldrich, St. Louis, MO) solution of $1.5 \mathrm{~h}$ and washed three times in water, transferred to soil and left without watering for 1 week (6).

\subsection{Chlorophyll Content}

Leaves were cut into small pieces and ground in a glass tissue grinder in the mixed acetone $(80 \%, 20 \mathrm{~mL})$ and magnesium carbonate $(0.5 \mathrm{~g})$ in order to extract chlorophyll (Chl) a-b and carotenoids from the DH and the donor plant 'Hyola 420'. The extract was centrifuged at $2000 \times \mathrm{g}$ for $10 \mathrm{~min}$ at $4{ }^{\circ} \mathrm{C}$ and the pellet was discarded. Spectrophotometric readings were made at 490, 663 and $645 \mathrm{~nm}$ to determine Chl a-b and carotenoids content according to Lichtenthaler and Wellburn (22).

\subsection{Protein Extraction}

Protein extraction from microspores was performed according to Man et al. (23) with some modifications. Isolated microspore suspensions following heat shock ( 2 days at $30^{\circ} \mathrm{C}$ ) and 2,4-D treatment (35 $\mathrm{mg} . \mathrm{L}^{-1}$ for $30 \mathrm{~min}$ ) were centrifuged at $150 \times \mathrm{g}$ for 5 min at $4^{\circ} \mathrm{C}$, the supernatant was decanted and TRIzol $(1 \mathrm{~mL})$ was added to the pellet. After incubating for 10 min at room temperature $\left(25^{\circ} \mathrm{C}\right)$, chloroform $(0.2 \mathrm{~mL})$ was added and vortexed for $15 \mathrm{~s}$. The mixture was incubated for $15 \mathrm{~min}$ at room temperature. The resulting suspension was centrifuged at $12000 \times g$ for $15 \mathrm{~min}$ at $4^{\circ} \mathrm{C}$ and the supernatant containing RNA was decanted. Ethanol $(0.3 \mathrm{~mL}, 100 \%)$ was added to the pellet and incubated for 2 min using gentle shaking. The suspension was centrifuged at $2000 \times g$ for $5 \mathrm{~min}$ at $4^{\circ} \mathrm{C}$ and the supernatant containing proteins was transferred to other tube. After adding acetone $(100 \%)$ and gentle shaking for $10 \mathrm{~min}$, the suspension was centrifuged at $12000 \times \mathrm{g}$ for $10 \mathrm{~min}$ at $4^{\circ} \mathrm{C}$. The supernatant was decanted and $2 \mathrm{~mL}$ of guanidine hydrochloride was added to the pellet and centrifuged again. This process was repeated twice. Ethanol (1 mL, 100\%) containing $2.5 \%$ glycerol was added to tube for $20 \mathrm{~min}$ and centrifuged at $10000 \times \mathrm{g}$. Ethanol was added to the pellet using gentle shaking and the tube was incubated for $10 \mathrm{~min}$ at room temperature until the pellet was dried. Finally, $0.2 \mathrm{~mL}$ of SDS (1\%) was added to the dried pellet, vortexed for $20 \mathrm{~min}$ and centrifuged at $10000 \times \mathrm{g}$ for $10 \mathrm{~min}$ at $4^{\circ} \mathrm{C}$. The pellet, containing protein, was stored at $-20^{\circ} \mathrm{C}$ until needed. For extraction of total soluble protein of leaves, $100 \mathrm{mg}$ of frozen plant material $\left(-80^{\circ} \mathrm{C}\right)$ was ground in liquid nitrogen, vortexed with $300 \mu \mathrm{L}$ extraction buffer $(100 \mathrm{mM}$ HEPES pH 7.1, $250 \mathrm{mM}$ sorbitol, $10 \mathrm{mM} \mathrm{MgCl}_{2}, 10$ mM KCl, 1 mM EDTA, 1 mM EGTA, 2 mM DTT, and $1 \mathrm{mM}$ PMSF), and centrifuged at $15000 \times \mathrm{g}$ for $20 \mathrm{~min}$ at $4^{\circ} \mathrm{C}$. The protein concentration of supernatant was measured using Bradford assay (24).

\subsection{Anatomical Features}

Length and width of stomata and pollen grains were photographed using light microscope (Olympus, Nagano and Japan) with digital camera (Canon power shot S80). The photographs were taken by Zoom Browser Ex program and the dimensions were measured using Corel Draw software version 12.

\subsection{Experimental Design and Statistical Analysis}

The experiments were conducted in completely randomized design (CRD) to evaluate the effect of two stressors. Each treatment had five replications. Data analyses were performed using SPSS software version 17 and the means were compared using Duncan's multiple range test (DMRT) at $\alpha=0.01$ following analysis of variance (ANOVA).

\section{Results}

Late unicellular microspores (suitable for rapeseed microspore culture, 11) were isolated (Figure 1A) and stained by DAPI to confirm the exact developmental 


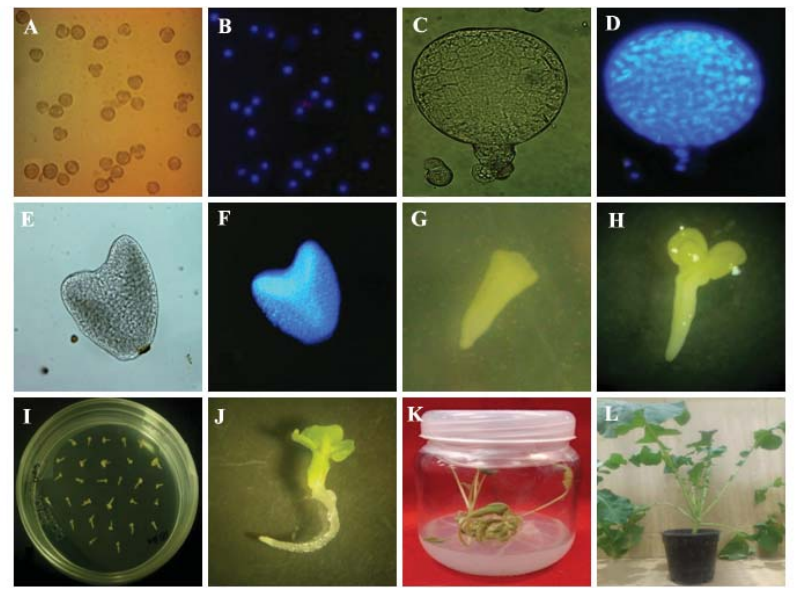

Figure 1. A,B: late unicellular microspores, C: globular embryo, D: DAPI-stained globular embryo,E: heart-shaped embryo, F: DAPI-stained heart-shaped embryo,G: torpedoshaped embryo, H: cotyledonary embryo, I,J: cotyledonary embryo transferred onto the B5 medium containing 0.1 mg.L-1 GA3, K: germinated embryo transferred onto hormone-free B5 medium for plantlet regeneration, L: fullydeveloped plantlet transferred into pots containing sterile peat and perlite

stage (Figure 1B). Successive MDE development was also documented under inverted microscope (Figure $1 \mathrm{C}$ and D: globular embryo, $1 \mathrm{E}$ and $\mathrm{F}$ : heart-shaped embryo, 1G: torpedo-shaped embryo and $1 \mathrm{H}$ : cotyledonary embryo). Cotyledonary MDEs were transferred onto the B5 medium containing $0.1 \mathrm{mg} . \mathrm{L}^{-1} \mathrm{GA}_{3}$ (Figure $1 \mathrm{I}$ and $\mathrm{J}$ ) and transferred onto the hormonefree B5 medium for plantlet regeneration (Figure 1K). Fully developed plantlets were transferred to pots containing sterile peat and perlite for acclimation (Figure $1 \mathrm{~L})$. Chromosome number of haploid plantlets were doubled using colchicine treatment.Anatomical and physiological characteristics were measured during flowering phase.

\subsection{Quantification of Proteins}

Total protein content of microspores and regenerated DH plants were significantly affected by applied stressors (Figure 2). The highest protein content was observed in untreated microspores $\left(9.1976 \mu \mathrm{g} . \mathrm{mL}^{-1}\right)$. The difference between heat shock $\left(8.7288 \mu \mathrm{g} . \mathrm{mL}^{-1}\right)$ and 2,4-D treated $\left(8.5666 \mu \mathrm{g} \cdot \mathrm{mL}^{-1}\right)$ microspores was not significant. The highest leaf protein content was obtained in heat shock treated DH plants (41.7584 $\left.\mathrm{mg} \cdot \mathrm{mL}^{-1}\right)$. No significant difference was observed between leaf protein content of the donor plant 'Hyola 420 ' and the DH plants obtained by 2,4-D treatment.
A

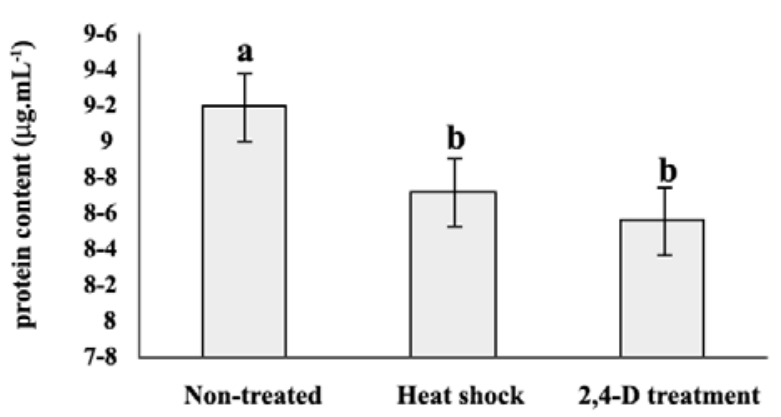

B

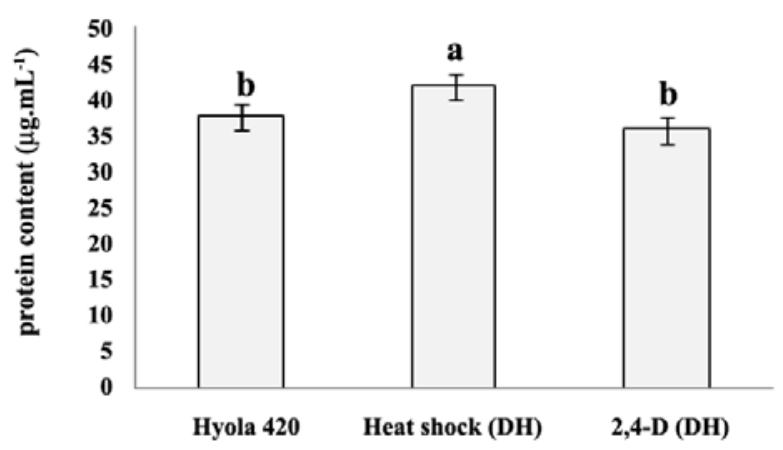

Figure 2. Effects of heat shock $\left(30 \pm 0.5^{\circ} \mathrm{C}\right.$ for 14 days $)$ and 2,4-D (35 mg.L $\mathrm{L}^{-1}$ for $30 \mathrm{~min}$ ) stress treatment on protein content of A: Microspores; B: regenerated DH plants. Means followed by the same letters are not significantly different according to DMRT $(P=0.01)$

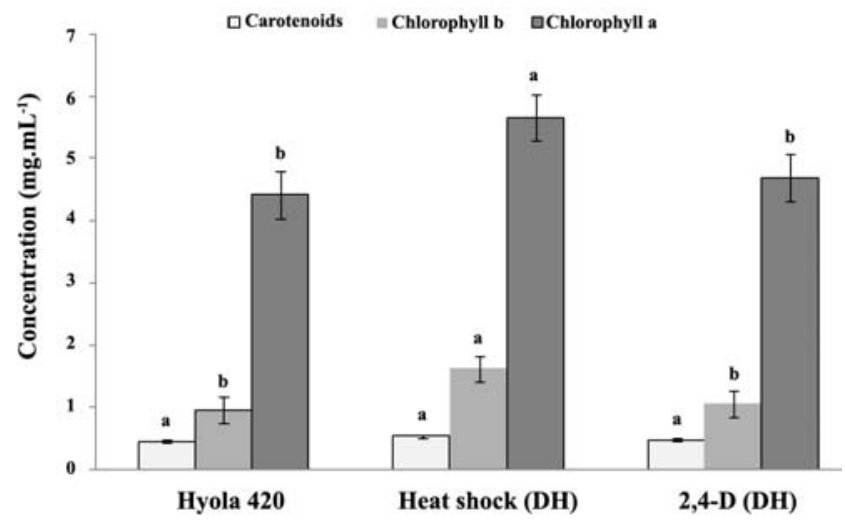

Figure 3. Effects of heat shock $\left(30 \pm 0.5^{\circ} \mathrm{C}\right.$ for 14 days $)$ and 2,4-D (35 mg.L. $\mathrm{L}^{-1}$ for $\left.30 \mathrm{~min}\right)$ stress treatment on carotenoid and $\mathrm{Chl}$ a-b content of regenerated DH plants. Means followed by the same letters are not significantly different according to DMRT $(P=0.01)$

\subsection{Pigments of Photosynthesis}

The concentration of main photosynthetic pigments (Chl a-b and carotenoids) in the donor plant 'Hyola 420' was compared with the DH plants (Figure 3). A 

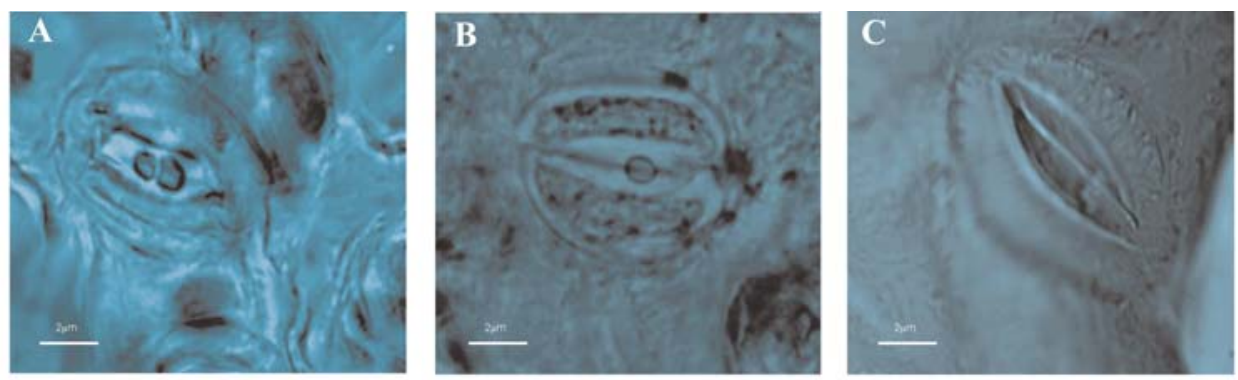

Figure 4. Length and width of stomata in, A: diploid; B: DH plants derived from heat stressand C: DH plants derived from $2,4-\mathrm{D}$ treatment; bar $=2 \mu \mathrm{m}$
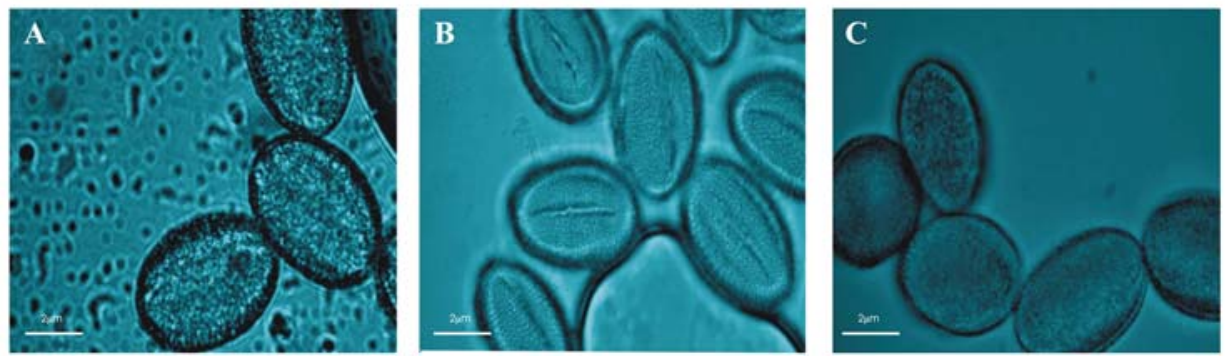

Figure 5. Length of pollen in, A: diploid; B: DH plants derived following heat stress and C: DH plants derived from 2,4-D treatment; $\mathrm{bar}=2 \mu \mathrm{m}$

significant difference between the concentrations of Chl a-b in 'Hyola 420' and the heat shock treated DH plants was evident. The highest concentration of Chla and $\mathrm{b}$ (5.6600 and $1.6191 \mathrm{mg} \cdot \mathrm{mL}^{-1}$, respectively) was observed in heat shock treated DH plants. However, carotenoids were more stable and were not affected by either heat shock or 2,4-D treatment.

\subsection{Length and Width of Stomata and Pollen Grains}

Morphological variation in size of stomata (Figures

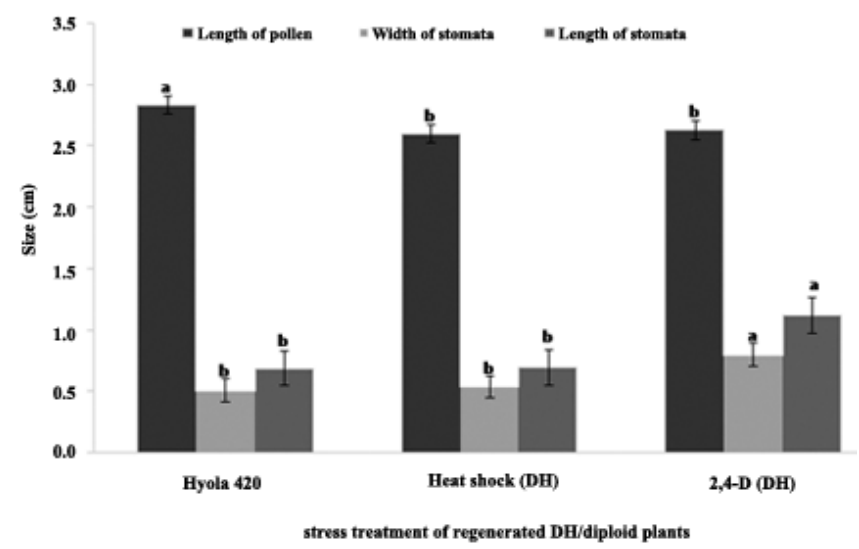

Figure 6. Effects of heat shock $\left(30 \pm 0.5^{\circ} \mathrm{C}\right.$ for 14 days $)$ and 2,4-D (35 mg.L $\mathrm{L}^{-1}$ for $30 \mathrm{~min}$ ) stress treatment on length and width of pollen and stomata of regenerated $\mathrm{DH}$ plants. Means followed by the same letters are not significantly different according to DMRT $(P=0.01)$
4,5) was also observed between $\mathrm{DH}$ plants derived from 2,4-D as a stressor with diploid and DH plants resulting from heat stress. Length and width of stomata and pollen grains were affected by applied stressors (Figure 6). Longer $(1.1296 \mathrm{~cm})$ and wider $(0.8085 \mathrm{~cm})$ stomata were observed in the DH plants treated by 2 , 4-D. Additionally, the differences between length and width of stomata in the donor plant 'Hyola 420' and the heat shock treated DH plants were not significant. The length of pollen grains significantly decreased in both heat shock treated and 2,4-D treated DH plants when compared with the donor plant 'Hyola 420'.

\section{Discussion}

Stress is an essential component for microspore embryogenesis (3). Plants respond variably to inductive stresses. These responses include varieties of morphological and physiological alterations that all depend on the degree and the complexity of stress type and the manner in which the stress is perceived by plant. According to our results, applied stressors i.e. heat shock $\left(30 \pm 0.5^{\circ} \mathrm{C}\right.$ for 14 days) and 2,4-D (35 $\mathrm{mg} . \mathrm{L}^{-1}$ for $30 \mathrm{~min}$ ) treatment, significantly reduced total protein content of treated microspores. Working on tobacco microspore embryogenesis, Garrido et al. (25) noted a decrease in the overall synthesis of protein content in microspores during a 7-day starvation (25). Protein degradation and inhibition of protein synthesis 
following inductive stresses are implicated in the switching microspore from gametophytic developmental pathway towards embryogenesis (26).

Ultra-structural studies in microspores of $B$. napus cv. "Topas" showed organelle-free regions in the cytoplasm of heat treated microspores (27), support the idea that the protein degradation and inhibition of protein synthesis may trigger a switch from gametophytic pathway towards microspore embryogenesis (28). In addition, some of the observed structural and biochemical changes suggest that a transient cell cycle arrest is needed prior to embryogenic commitment (29). Such a phase of metabolic quiescence during the induction period is necessary for cytoplasmic reorganization and the generation of an autophagic response that would eliminate the weakest microspores (30). However, according to our results, the difference between protein content of the heat shock $\left(8.7288 \mu \mathrm{g} . \mathrm{mL}^{-1}\right)$ and 2,4-D treated $\left(8.5666 \mu \mathrm{g} . \mathrm{mL}^{-1}\right)$ microspores was not significant.

Leaf protein content was also affected by heat shock and 2,4-D treatment in the derived DH plants. According to our results, the highest total protein content (41.7584 mg. $\mathrm{mL}^{-1}$ ) was observed in the DH plants obtained by heat shock treatment. However, Gulen and Eris (31) noted that both gradual heat stress (increased stepwise by $5^{\circ} \mathrm{C} / 48 \mathrm{~h}$ up to $30-45^{\circ} \mathrm{C}$ ) and constant heat stress $\left(30-45^{\circ} \mathrm{C}\right)$ conversely affected total protein content in strawberry (Fragaria $\times$ ananassa cv. Camarosa).Thus, temperature incline leads to protein content reduction. This might be due to protein denaturation and inhibition of newly protein synthesis at high temperatures, since the injury from high temperature has often been attributed to the denaturation of proteins (31). Similar results were observed by $\mathrm{He}$ et al. (32) in creeping bentgrass. The plant total protein content in response to heat stress seems to be species/genotype dependent (33). Thermo-tolerant species/genotypes have significantly higher total protein content and newly synthesized proteins compared to the less thermo-tolerant species/genotypes during prolonged period of heat stress $(33,34)$. The decline in the content of total or newly synthesized proteins suggests that protein degradation rates exceed protein synthesis rates during heat stress. Thermo-tolerant species/genotypes may be able to sustain protein synthesis better and/or posses relatively more thermo-stable proteins i.e. heat shock proteins during heat stress (33). In this study, 2,4-D treatment did not affect total protein content of the derived $\mathrm{DH}$ plants in comparison with the donor plant 'Hyola 420'. Information about regulatory role(s) of 2,4-D treatment on protein content of plants is rather limited. However, Kumar (35) noted that 2,4-D treatment (50-1200 ppm) reduced total protein content gradually from lower to higher concentration in Triticum aestivum L. at normal laboratory temperature $\left(25 \pm 2^{\circ} \mathrm{C}\right)$.

The highest concentration of Chl a-b (5.6600 and $1.6191 \mathrm{mg} \cdot \mathrm{mL}^{-1}$, respectively) was observed in the $\mathrm{DH}$ plants derived following heat shock treatment. Working on coffee seedlings, Oliviera et al. (36) noted that temperature ranging from $10^{\circ} \mathrm{C}$ to $25^{\circ} \mathrm{C}$ caused $\mathrm{Chl} \mathrm{a}-\mathrm{b}$ accumulation in the seedlings' cotyledonary leaves. However, inhibitory effect of higher temperatures $\left(>37^{\circ} \mathrm{C}\right)$ on $\mathrm{Chl}$ a-b accumulation has been reported $(37,38)$. Chlorophylls (a and b) are known to be easily degraded by conditions such as dilute acids, high temperatures and in response to abiotic stresses $(39,40)$. In this study, Chlorophylls (a and b) content were not affected in the DH plants treatedby 2,4-D in comparison with'Hyola 420'. However, Setyaningrum (41), noted that 2,4-D (1 mg.L-1) markedly increased Chl a-b content in alfalfa callus (Medicago sativa L.).

According to our results, carotenoids were more stable in comparison with $\mathrm{Chl} \mathrm{a-b}$ and its content was not affected by stressors used in this study. Working on Coriandrum staivum L., Kumar et al. (42) noted that 2,4-D $(10-100 \mu \mathrm{M})$ did not affect carotenoid content in treated seedling. However, instability of carotenoids is observed in other species upon high temperatures $\left(>50^{\circ} \mathrm{C}\right)$ regimes $(43)$ and $2,4-\mathrm{D}$ treatment $(41)$. Urrea et al. (42) observed $15.0 \%, 17.7 \%$ and $25.4 \%$ degradation of carotenoids at 50,60 and $80^{\circ} \mathrm{C}$, respectively in carrot (Daucus carota). Furthermore, 2,4-D (1 mg.L-1) application increased carotenoid content in callus of M. sativa L. (41).

Heat shock and 2,4-D treatment significantly decreased the length of pollen grains in comparison with 'Hyola 420'. The differences between pollen length of the DH plants obtained from heat shock and 2,4-D treatment were not significant. However, Jacobsen and Martens (44) reported that the diameter of pollen grains in Trifolium repens L. was influenced by developmental temperatures. In their report, the pollen grains developed at $10^{\circ} \mathrm{C}$ were $2.3 \mu \mathrm{m}$ smaller in diameter on average in compared to those formed at $18^{\circ} \mathrm{C}$. High temperature affects the growth and development of pollen grains, which in turn impinge on seed formation and development (45). Within a flower, anthers and pollen grains are more sensitive to heat shock than ovules, and floret sterility at temperatures $\geq 30^{\circ} \mathrm{C}$ has been correlated with diminished anther 
dehiscence (46), production of fewer pollen grains, pollen sterility (47) and reduced in vivo pollen germination (48).

Length and width of the stomata were also affected by applied stressors and longer and wider stomata were observed in the DH plants treated by 2,4-D. Working on woody species e.g. Chromolaena adorata, Griffonia simplicifolia and Morinda lucida, Mensah (49) reported that the stomatal dimensions (width and length) of those species had adaptation mechanisms to the stress environment in which high temperatures (mainly in the afternoon) significantly decreased the length and width of the stomata. Stomatal behavior could be an innate ability to adapt to the environmental stresses i.e. drought and high temperatures (49).

\section{Conclusions}

Stress is needed to deviate the developmental fate of cultured isolated microspores from gametophytic towards embryogenesis. Plants respond to such stresses via morphological and physiological adjustments. Two inductive stresses (2,4-D and heat shock) were studied and morphological and physiological characteristics of treated microspores and derived DH plants were analyzed. Total protein contents of treated microspores drastically decreased but total protein content of derived DH plants significantly increased following stress application. Both Chla and $\mathrm{b}$ were increased after heat shock treatment. 2,4-D treatment resulted in wider and longer stomata in the derived $\mathrm{DH}$ plants when compared with the donor plants and the DH plants following treatment by heat.

\section{Funding/Support}

This research was supported by grants from Agricultural Biotechnology Research Institute of Iran (ABRII) project No.1-05-05-8601.

\section{References}

1. Touraev A, Pfosser M, Heberle-Bors E. The microspore: a haploid multipurpose cell. Adv Bot Res. 2001;35:53-109. DOI: 10.1016/S0065-2296(01)35004-8

2. Palmer CE, Keller WA, Arnison PG. Utilization of Brassica haploids. In: Jain SM, Sopory SK, Veilleux RE (eds) In vitro haploid production in higher plants. Kluwer Academic Publishers, Dordrecht, The Netherlands. 1996;p.173-199. DOI: 10.1007/978-94-017-1858-5_10

3. Shariatpanahi ME, Bal U, Heberle-Bors E, Touraev A. Stresses applied for the re-programming of plant microspores towards in vitro embryogenesis. Physiol Plant. 2006;127:519-534. DOI: $10.1007 / \mathrm{s} 11240-013-0408-\mathrm{x}$

4. Ferrie AMR, Caswell KL. Isolated microspore culture techniques and recent progress for haploid and doubled haploid plant production. Plant Cell Tiss Org Cult. 2011;104:301-309. DOI: $10.1007 / \mathrm{s} 11240-010-9800-y$

5. Ahmadi B, Shariatpanahi ME, Teixeira da Silva JA. Efficient induction of microspore embryogenesis using abscisic acid, jasmonic acid and salicylic acid in Brassica napus L. Plant Cell Tiss Org Cult.2014;116:343-351. DOI: 10.1111/j.13993054.2006.00675.x

6. Ferrie AMR, Taylor DC, MacKenzie SL, Keller WA. Microspore embryogenesis of high $s n-2$ erucic acid Brassica oleracea germplasm. Plant Cell Tiss Org Cult. 1999;57:7984. DOI: $10.1007 / \mathrm{s} 11240-013-0408-\mathrm{x}$

7. Prem D, Gupta K, Agnihotri A. Effect of various exogenous and endogenous factors on microspore embryogenesis in Indian mustard (Brassica juncea L. Czern and Coss). In Vitro Cell Dev Biol Plant. 2005;41:266-273. DOI: 10.1079/IVP 2005636

8. Ahmadi B, Ghadimzadeh M, Moghaddam AF, Alizadeh K, Teixeira da Silva JA. Bud length, plating density, and incubation time on microspore embryogenesis in Brassica napus. Int J Vegetable Sci. 2012a;18:346-357. DOI: 10.1080/19315260. 2011.647265

9. Ferrie AMR, Keller WA. Optimization of methods for using polyethylene glycol as a non-permeating osmoticum for the induction microspore embryogenesis in the Brassicacea. In Vitro Cell Dev Biol Plant. 2007;43:348-355. DOI: 10.1007/s 11627-007-9053-6

10. Ardebili SH, Shariatpanahi ME, Amiri R, Emamifar M, Nematzadeh G, Sadat Noori SA, Oroojloo M, Heberle-Bors E. Effect of 2,4-D as a novel inducer of embryogenesis in microspores of Brassica napus L. Czech J Genet Plant Breed. 2011;47:114-122.

11. Ahmadi B, Alizadeh K, Teixeira da Silva JA. Enhanced regeneration of haploid plantlets from microspores of Brassica napus L. using bleomycin, PCIB, and phytohormones. Plant Cell Tiss Org Cult. 2012b;109:525-533. DOI: 10.1007/s 11240-012-0119-8

12. Liu GS, Li Y, Liu F, Cao MQ. The influence of high temperature on the cultures of isolated microspores of Chinese cabbage. Acta Bot Sin. 1995;37:140-146.

13. Fan Z, Armstrong KC, Keller WA. Development of microspores in vivo and in vitro in Brassica napus $\mathrm{L}$. Protoplasma. 1998;147:191-199.

14. Kim SW, In DS, Kim TJ, Liu JR. High frequency somatic embryogenesis and plant regeneration in petiole and leaf explants cultures and petiole-derived embryogenic cell suspension cultures of Hylomeconvernalis. Plant Cell Tiss Org Cult. 2004;74:163-167. DOI: 10.1023/A:1023997627578

15. Raghavan V. Role of 2,4-dichlorophenoxyacetic acid (2,4-D) in somatic embryogenesis on cultured zygotic embryos of Arabidopsis: cell expression, cell cycling, and morphogenesis during continuous exposure of embryos to 2,4-D. Amer J Bot. 2005;91:1734-1756.

16. Gaj MD. Factors influencing somatic embryogenesis induction and plant regeneration with particular reference to Arabidopsis thaliana L. Heynh Plant Growth Regul. 2004;43:27-47. DOI: 10.1023/B:GROW.0000038275.29262. fb

17. Grover A, Kapoor A, Katyiar-Agarwal S, Agarwal M, Sahi C, Jian P, Kotak S, Agarwal S, Dubey H. Experimentation in biology of plant abiotic stress responses. Proc Indian Natn Sci 
Acad. 2001;6:189-214.

18. Lichter R. Induction of haploid plants from isolated pollens of Brassica napus. Z. Pflanzenphysiol. 1982;105:427-434. DOI: 10.1016/S0044-328X(82)80040-8s

19. Gamborg OL, Miller RA, Ojima L. Nutrient requirements of suspension cultures of soybean root cells. Exp Cell Res. 1968;50:151-158. DOI: 10.1016/0014-4827(68)90403-5

20. Otto F. DAPI staining of fixed cells for high resolution flow cytometry of nuclear DNA. In: Crissman HA, Darzynkiewicz Z (eds) Methods in cell biology. Academic Press, Inc New York. 1990;p.105-110.

21. Hause G, Hause B, Van Lammeren AAM. Microtubular and actin filament conFigureurations during microspore and pollen development in Brassica napus L. cv. Topas. Can J Bot. 1992;70:1369-1376.

22. Lichtenthaler HK, Wellburn AR. Determination of total carotenoids and chlorophylls a and b of leaf extracts in different solvents. BiochemSoc Trans. 1983;603:591-592.

23. Man TK, Li Y, Dang TA, Shen J, Perlaky L, Lau CC. Optimizing the use of TRIzol-extracted proteins in Surface Enhanced Laser Desorption/Ionization (SEDLI) analysis. Proteom Sci. 2006;4:1-7. DOI: 10.1186/1477-5956-4-3

24. Heiss S, Wachter A, Bogs J, Cobbett C, Rausch T. Phytochelatin synthase (PCS) protein is induced in Brassica juncea leaves after prolonged $\mathrm{Cd}$ exposure. J Exp Bot. 2003;54:1833-1839. DOI: 10.1093/jxb/erg205

25. Garrido D, Eller N, Heberle-Bors E, Vicente O. De novo transcription of specific messenger RNAs during the induction of tobacco pollen embryogenesis. Sex Plant Reprod. 1993;6:4045. DOI: 10.1007/BF00227581

26. Harada H, Kyo M, Imamura J. The induction of embryogenesis in Nicotiana immature pollen culture, In: Bock G, Marsh J (eds) Applications of Plant Cell and Tissue Culture. Willey, Chichester. 1988;p.59-74.

27. Telmer CA, Newcomb W, Simmonds DH. Microspore development in Brassica napus and the effect of high temperature on division in vivo and in vitro. Protoplasma. 1993;172:154165. DOI: 10.1007/BF01379373

28. Zhao J, Newcomb W, Simmonds D. Heat-shock proteins 70 $\mathrm{kDa}$ and $19 \mathrm{kDa}$ are not required for induction of embryogenesis of Brassica napus L. cv. Topas microspores. Plant Cell Physiol. 2003;44:1417-1421. DOI: 10.1093/pcp/pcg162

29. Seguý-Simarro JM, Nuez F. How microspores transform into haploid embryos: changes associated with embryogenesis induction and microspore-derived embryogenesis. Physiol Plant. 2008;134:1-12. DOI: 10.1111/j.1399-3054.2008. 01113.x

30. Hosp J, Maraschin SDF, Boutilier K. Functional genomics of microspore embryogenesis. Euphytica. 2007;158:275-285. DOI: $10.1007 /$ s10681-006-9238-9

31. Gulen H, Eris A. Effect of heat stress on peroxidase activity and total protein content in strawberry plants. Plant Sci. 2004;166:739-744. DOI: 10.1016/j.plantsci.2003.11.014

32. He Y, Liu X, Huang B. Changes in protein content, protease activity, and amino acid content associated with heat injury in creeping bentgrass. J AmerSocHort Sci. 2005;130:842-847.

33. Huang B, Rachmilevitch $\mathrm{S}, \mathrm{Xu}$ J. Root carbon and protein metabolism associated with heat tolerance. J Exp Bot. 2012;63:3455-3465. DOI: 10.1093/jxb/ers003
34. Xu C, Huang B. Root proteomic responses to heat stress in two Agrostis grass species contrasting in heat tolerance. J Exp Bot. 2009;59:4183-4194. DOI: 10.1093/jxb/ern258

35. Kumar S. Effect of herbicides on carbohydrate, protein and electrophoretic protein bands content in Triticumaestivum L. Int J Food Agri Vet Sci. 2012;2:13-25.

36. Oliviera JGD, Costa Aguiar Alves PLD, Vitória AP. Alterations in chlorophyll a fluorescence, pigment concentrations and lipid peroxidation to chilling temperature in coffee seedlings.Environ Exp Bot. 2009;67:71-76.

37. Erge HS, Karadeniz F, Koca N, Soyer Y. Effect of heat treatment on chlorophyll degradation and color loss in green peas. Gida.2008;33:225-233.

38. Efeoglo B, Terzioglo S. Photosynthetic responses of two wheat cultivars to high temperature. Eur Asia J BioSci. 2009;3:97-106.

39. Mur LAJ, Aubry S, Mondhe M, Kingston-Smith A, Gallagher J, Timms-Taravella E, James C, Papp I, Hörtensteiner S, Thomas H, Ougham H. Accumulation of chlorophyll catabolites photosensitizes the hypersensitive response elicited by Pseudomonas syringae in Arabidopsis. New Phytol. 2010;188:161-174.

40. Brouwer B, Ziolkowska A, Bagard M, Keech O, Gardeström P. The impact of light intensity on shade-induced leaf senescence.Plant Cell Environ. 2012;35:1084-1094.

41. Setyaningrum R. The effectiveness of 2,4-Dichlorophenoxy acetic acid $(2,4-\mathrm{D})$ and kinetin on induction and chlorophyll and carotenoid content of alfalfa (Medicago sativa L.) callus. Undergraduate Thesis, University of Diponegoro. 2011.

42. Kumar M, Agnihotri PK, Valim R, Sharma R. Effect of phytohormones on seed germination and seedling growth of Coriandrumsativum L. Pakistan J Biol Sci. 2014;17:594-596.

43. Urrea D, Eim VS, González-Centeno MR, Minjares-Fuentes R, Castell-Palou JMD, Rosselló C. Effects of air drying temperature on antioxidant activity and carotenoids content of carrots (Daucuscarota). European Drying ConferenceEuroDrying. 2011;p.26-28.

44. Jacobsen HB, Martens H. Influence of temperature and ageing of ovules and pollen on reproductive success in Trifoliumrepens L. Annal Bot. 1994;74:493-501.

45. Ledesma N, Sugiyama N. Pollen quality and performance in strawberry plants exposed to high-temperature stress. $J$ AmerSocHort Sci. 2005;130:341-347.

46. Matsui T, Omasa K, Horie T. High temperature at flowering inhibits swelling of pollen grains, a driving force for thecae dehiscence in rice. Plant Prod Sci. 2000;3:430-434.

47. Prasad PVV, Boote KJ, Allen Hartwell LJ. Adverse high temperature on pollen viability, seed-set, seed yield and harvest index of grain-sorghum [Sorghum bicolor (L.) Moench] are more severe at elevated carbon dioxide due to higher tissue temperature. Agri Forest Meteorology. 2006;139:237-251.

48. Jagadish SVK, Muthurajan R, Oane R, Wheeler TR, Heuer S, Bennett J, Craufurd PQ. Physiological and proteomic approaches to address heat tolerance during anthesis in rice (Oryza sativa L.). J Exp Bot. 2010;61:143-156.

49. Mensah DB. Leaf anatomical variation in relation to stress tolerance among some woody species on the Accra plants of Ghana. J Plant Dev. 2012;19:13-22. 